\begin{tabular}{|l|r|}
\hline APIC Analisa Pemikiran Insan Cendikia & ISSN: 2654-7201 \\
Volume IV, No. 1 (2021) 01 - 18 & e-ISSN : 0000-0000 \\
\hline
\end{tabular}

\title{
PENGARUH PENDEKATAN OPEN-ENDED DAN MOTIVASI BELAJAR TERHADAP KEMAMPUAN BERPIKIR KREATIF SISWA
}

\author{
Nur'Afifah $^{1}$ Gunarno $^{2}$ \\ ${ }^{1}$ Program Studi Pendidikan Matematika Universitas Muhammadiyah Sumatera Utara \\ ${ }^{2}$ Balai Pendidikan dan Pelatihan Keagamaan Medan
}

Balai Diklat Keagamaan Medan J1. TB. Simatupang No. 122 Medan Telp. (061)8456256

E-mail: ${ }^{1}$ nurafifah@umsu.ac.id

${ }^{2}$ narnowibdkmdn@ gmail.com Naskah diterima: 21 April 2021 Naskah Direvisi: 21-28 April 2021

Naskah disetujui: 30 April 2021 Website Journal:

http://apicbdkmedan.kemenag.go.id

\section{ABSTRAK}

Tujuan penelitian ini adalah: (1) mengetahui pengaruh pembelajaran dengan pendekatan open-ended terhadap kemampuan berpikir kreatif siswa, (2) mengetahui pengaruh motivasi belajar terhadap kemampuan berpikir kreatif siswa. Penelitian ini merupakan penelitian eksperimen semu (quasi experiment) yang dilakukan di FKIP UMSU Prodi Pendidikan Matematika. Pemilihan sampel yang dijadikan kelompok eksperimen dan kelompok kontrol dilakukan secara random(random sampling). Sampel penelitian berjumlah 58 orang yang terdiri dari semester IV-A berjumlah 30 orang sebagai kelas eksperimen dan semester IV-B berjumlah 28 orang siswa sebagai kelas kontrol. Variabelvariabel dalam penelitian ini adalah pendekatan pembelajaran yang terdiri dari pendekatan open-ended dan ekspositori sebagai variabel bebas aktif, dan motivasi belajar siswa yang terbagi atas motivasi belajar tinggi, sedang, reandah sebagai variabel moderator, kemampuan berpikir kreatif siswa sebagai variabel terikat. Instrumen yang digunakan dalam penelitian ini adalah: yaitu tes kemampuan berpikir kreatif. Instrumen penelitian untuk mengukur kemampuan berpikir kreatif siswa digunakan tes uraian dengan jumlah soal sebanyak 5 butir dengan koefisien reabilitas 0,829 (sangat tinggi). Sebelum teknik analisa digunakan terlebih dahulu diuji persyaratan analisisnya yaitu normalitas dan homogenitas data. Uji normalitas dan diuji dengan uji Liliefors sedangkan uji homogenitas diuji dengan uji Barlett (pengolahan data dengan SPSS 20). Teknik analisa data adalah Anava dua jalur pada taraf signifikan $\alpha=0,05$ yang dilanjutkan dengan uji Scheffe. Perangkat pembelajaran yang digunakan adalah: (1) Rencana Pembelajaran Semester (RPS), (2) Lembar Aktivitas Mahasiswa (LAM), (3) Buku Siswa. Tes pemecahan masalah menggunakan tes uraian dengan menekankan pada kreatifitas. Data dalam penelitian ini dianalisis dengan menggunakan analisis statistik deskriptif dan analisis inferensial. Analasis deskriptif ditujukan untuk mendeskripsikan hasil kemampuan berpikir kreatif, dan aktivitas siswa terhadap pembelajaran. Sedangkan analisis statistik inferensial digunakan untuk melihat apakah ada perbedaan dalam hal kemampuan berpikir kreatif antara siswa yang diajarkan dengan pendekatan open-ended dengan siswa yang diajarkan dengan pendekatan ekspositori. Hasil penelitian menunjukkan bahwa: (1) ada perbedaan dalam hal kemampuan berpikir kreatif antara siswa yang mendapat pembelajaran dengan pendekatan open-ended dengan siswa yang mendapat pembelajaran dengan pendekatan ekspositori. Siswa yang dibelajarkan dengan pendekatan open-ended secara keseluruhan memperoleh kemampuan berpikir kreatif siswa dengan $\bar{X}=9,9$ lebih tinggi dari siswa yang diajar dengan pendekatan ekspositori dengan $\bar{X}=6,1$; diperoleh $F_{\text {hitung }}=124,44>F_{\text {tabel }}=4,01$; (2) ada perbedaan kemampuan berpikir kreatif antara siswa yang memilki motivasi belajar tinggi, sedang dan rendah. Rata-rata keseluruhan kemampuan berpikir kreatif siswa yang memiliki motivasi belajar tinggi $(\bar{X}=14,7)$ lebih tinggi daripada siswa yang memiliki motivasi belajar sedang $(\bar{X}=8,1)$ dan lebih tinggi daripada siswa yang memiliki motivasi belajar rendah $(\bar{X}=4,4)$ diperoleh $F_{\text {hitung }}=143,869>F_{\text {tabel }}=3,16$. Dari hasil analisis data disimpulkan bahwa secara umum kemampuan berpikir kreatif siswa yang dibelajarkan dengan pendekatan open-ended lebih tinggi daripada siswa yang dibelajarkan dengan pendekatan ekspositori. Apabila dilihat dari karakteristik siswa, kemampuan berpikir kreatif siswa yang memiliki motivasi belajar tinggi lebih tinggi daripada yang memiliki motivasi belajar sedang dan lebih tinggi daripada yang memiliki motivasi belajar rendah. Kata kunci: pendekatan Open Ended, motivasi belajar, dan berpikir kreatif ABSTRACT 
The objectives of this research: (1) to study the influence of teaching by open-ended approach to the creative thinking capability of student, (2) to study the influence of learning motivation to the creative thinking capability of student, (3) to study whether there is or not interaction between the learning approach by student learning motivation in influence the creative thinking capability of student. This research is a quasi experiment that conducted at SMP Swasta Dharma Bakti Lubuk Pakam (Private Junior High School). The sample for experiment and control groups were took by random sampling. The sample of research is 58 students that consist of from the Grade VII for 30 student as experiment class and from Grade VIIb for 28 students as control class. Variables in this research is learning approach that consist of open-ended approach and expository as active independent variable and student learning motivation that consist of higher, medium, lower learning motivation as moderator variable, creative thinking capability of student as dependent variable. The applied instrument in this research are (1) creative thinking capability test, (2) questioner of learning motivation. While instrument in this research to measure the creative thinking capability of student is a essay test with 5 test item and reliability coefficient is 0.829 (higher) The data of student learning motivation was collected by questionnaire with 30 items that adopted from Sembiring. Before the implementation of analysis method, its analysis requirement is tested by normality and homogeneity test. Normality is tested by Liliefors test while homogeneity is tested by Barlett test (data processing by SPSS 20). The method of data analysis is Anova with two path on significant level $\alpha=0.05$ that continued by Scheffee test. The teaching instrument are (1) Teaching Implementation plan (RPP), (2) Student Activity test, (3) Book of Student. The test of problem solving is essay test focused to the creativity. The data in this research is analyzed by using descriptive statistic analysis and inferential analysis. The descriptive analysis is aimed to describe the creative thinking capability, learning motivation of student and student activity in teaching learning process. While the inferential statistic analysis is used to study whether there is a difference in the creative thinking capability of student that taught by open ended approach and the student taught by expository approach. The results of research indicated that (1) there is a difference in creative thinking capability of student who taught by open-ended approach to the student who taught by expository approach. The student taught by open ended approach have a student creative thinking capability with $\overline{\mathrm{X}}=9.9$ that higher than student whoi taught by expository approach with $\overline{\mathrm{X}}=6.1$; it get $F_{\text {calculated }}=124.44>F_{\text {table }}=4.01 ;(2)$ there is a difference in creative thinking capability between student with the higher, medium and lower learning motivation. The average of student cretive thinking capability with the higher learning motivation $\overline{\mathrm{X}}=14.7$ is higher than student with the medium learning motivation $\bar{X}=8.1$ and higher than student with the lower learning motivation $\overline{\mathrm{X}}=4.4$ in which $F_{\text {calculated }}=143.869>F_{\text {tabgle }}=3.16$. Based on the data analysis is concluded that the student creative thinking capability that taught by open ended approach is higher than student that taught by expository approach. According to the characteristics of student, the student creative thinking capability with the higher learning motivation is higher than student with the medium learning motivation and higher than student with the lower learning motivation.

Key Word: Open-Ended Approach, Learning Motivation, and Creative Thinking

\section{PENDAHULUAN}

Pada Era revolusi 4.0 perkembangan Ilmu Pengetahuan dan Teknologi (IPTEK) diperlukan sumber daya manusia yang memiliki keterampilan yang tinggi yang melibatkan pemikiran kritis, sistematis, logis dan kreatif serta kemampuan bekerja sama yang efektif. Cara berpikir tersebut harus dapat dikembangkan melalui pembelajaran matematika.

Cornelius (dalam Abdurrahman, 2003:253) mengemukakan ada lima alasan perlunya belajar matematika yaitu karena matematika merupakan sarana berpikir yang jelas dan logis, sarana untuk memecahkan masalah kehidupan sehari-hari, sarana mengenal pola-pola hubungan dan generalisasi pengalaman, sarana untuk mengembangkan kreativitas, dan sarana untuk meningkatkan kesadaran terhadap perkembangan budaya. Salah satu tujuan pembelajaran matematika adalah memecahkan masalah yang meliputi kemampuan memahami masalah, merancang model matematika, menyelesaikan model dan 
menafsirkan solusi yang diperoleh. Untuk mencapai tujuan itu diperlukan kreativitas yang melibatkan imajinasi, intuisi dan penemuan dengan mengembangkan pemikiran yang divergen, orisional, rasa ingin tahu, membuat prediksi dan dugaan serta mencoba-coba. Dengan demikian mengisyaratkan pentingnya kreativitas dalam pembelajaran matematika (Siswono, 2005:1). Menyadari akan pentingnya kreativitas dalam pembelajaran matematika maka diperlukan pembelajaran yang kreatif. Namun, jika dilihat dari pembelajaran yang berlangsung di sebagian besar sekolah selama ini memberikan dampak yang sebaliknya dari yang diharapkan. Para siswa memang memiliki sejumlah pengetahuan, namun banyak pengetahuan itu diterima dari guru sebagai informasi, sedangkan mereka sendiri tidak dibiasakan untuk mencoba sendiri pengetahuan mereka. Mereka hanya duduk mendengarkan penjelasan guru, mencatat pelajaran, kemudian mengerjakan soal-soal rutin sehingga menjadi tidak bermakna dan cepat terlupakan. Dengan kata lain pembelajaran masih berpusat pada guru. Jika hal ini dikembangkan secara terusmenerus, maka akan mengakibatkan masalah bagi siswa dan pengajar.

Kreativitas dapat dijadikan sebagai pengukur hasil belajar. Kreativitas merupakan aspek penting dalam pendidikan. Menjadi kreatif berarti melakukan pembaharuan atau melakukan perubahan pada hal-hal yang telah ada. Oleh karena itu pembelajaran yang kreatif berbeda dengan gambaran pembelajaran pada umumnya yaitu monoton dan membosankan (Pannen, 2004:1). Jika hal ini dikembangkan secara terus-menerus, maka akan mengakibatkan masalah bagi siswa dan pengajar.

Munandar (dalam Siswandi, 2009) mengatakan bahwa guru mempunyai dampak yang besar tidak hanya pada prestasi pendidikan, tetapi juga pada sikap mahasiswa terhadap prodi matematika dan terhadap belajar pada umumnya. Rendahnya kualitas pendidikan di Indonesia dapat dilihat dari gaya mengajar dosen dikarenakan dampak kedepan bagaimana cara mengajar dosen akan ditiru oleh mahasiswa untuk kedepan jika sudah terjun menjadi seorang guru. Cara pembelajaran konsep cenderung abstrak dan menggunakan metode ceramah sehingga konsep-konsep akademik menjadi sulit untuk dipahami siswa. Selain itu dosen mengajar dengan tidak memperhatikan kemampuan berpikir kreatif mahasiswa atau dengan kata lain tidak melakukan pengajaran yang kreatif.

Ditinjau dari segi pengajaran, Karnasih dalam makalahnya (1997:3), mengatakan bahwa kegagalan menguasai matematika itu disebabkan oleh beberapa hal antara lain:

1) Pengajaran yang sifatnya rutin dan terfokus pada keterampilan menggunakan prosedur dan bukan pengajaran untuk menanamkan pengertian (teaching for understanding) ataupun pemecahan masalah (problem solving).

2) Pengajaran yang kurang melatih peserta didik untuk memiliki rasa percaya diri (self confidence) akan kemampuan dalam memecahkan masalah dalam matematika.

Untuk menjadi kreatif, dosen ditantang untuk menciptakan pembaharuan dalam proses pembelajaran, yaitu dengan melakukan pembaharuan pendekatan, penggunaan bahanbahan dan media pembelajaran, tahapan pembelajaran, gaya penilaian, dan lingkungan belajar (Pannen, 2004:9). Dalam pelaksanaan maupun proses pembelajaran, untuk mengetahui keberhasilan mahasiswa, guru perlu mengadakan penilaian termasuk pembelajaran yang bertujuan mengembangkan kemampuan berpikir kreatif mahasiswa. Penilaian (assessment) tersebut berguna untuk mendiagnosis kekuatan dan kelemahan mahasiswa, memonitor kemajuan mahasiswa, memberikan nilai/peringkat/tingkat (grade) mahasiswa dan menentukan keefektifan pembelajaran (Popham dalam Ali, 2008).

Edward De Bono (dalam Hassoubah, 2007:20) berpendapat bahwa banyak orang cerdas atau pintar tetapi bukan tipe pemikir yang baik. Tingkat kreativitas yang genius mungkin bergantung pada kualitas khusus (seperti kemampuan membayangkan) sebagaimana orang idiot savant yang memiliki kemampuan khusus. Meskipun berbagai upaya telah dilakukan untuk meningkatkan hasil belajar khususnya belajar matematika, namun sejauh ini hasil belajar tersebut samakin menurun dan tidak menunjukkan adanya peningkatan yang cukup berarti (signifikan). Fenomena yang tersebut dapat terlihat dari 
hasil belajar mahasiswa prodi pendidikan matematika pada matakuliah Kapita Selekta terutama materi segiempat dan segitiga masih mengalami penurunan. Yang menjadi penyebab kualitas mahasiswa tersebut menurun jika dikaitkan dengan pembelajaran yang diterapkan selama ini yaitu diantaranya disebabkan karena dalam pembelajaran siswa terlihat kurang aktif dalam mengikuti pembelajaran. Mahasiswa jarang sekali bertanya maupun mengutarakan ide-idenya. Keaktifan mahasiswa untuk mengerjakan soalsoal latihan pada proses pembelajaran masih kurang. Hal ini dikarenakan mahasiswa masih terbiasa mengerjakan soal-soal rutin dimana teknik penyelesaian soal tersebut berpedoman pada penerapan rumus secara langsung, contoh: menghitung luas kebun yang berbentuk persegi panjang dimana diketahui panjang $(\mathrm{p})=2 \mathrm{~m}$ dan lebar $(1)=5 \mathrm{~m}$. Dengan berpedoman pada rumus luas persegi panjang $=\mathrm{p} \times 1$ maka luas kebun tersebut $=2 m \times 5 m=10 m^{2}$. Demikian hal-hal tersebut dikemukakan oleh salah satu dosen prodi matematika di FKIP UMSU (Ibu, Putri maysarah, S.Pd.I, M.Pd).

Keragaman masalah tersebut menggambarkan efektivitas pembelajaran. Jika diamati kenyataan, efektivitas pembelajaran masih dikategorikan rendah. Hal ini tentunya terkait dengan pendekatan pembelajaran yang digunakan dosen. Pendekatan pembelajaran yang digunakan dosen hendaknya dapat memacu serta mengembangkan kreativitas mahasiswa dalam memecahkan masalah matematika.

Saat ini banyak sekali metode atau pendekatan yang dapat dilakukan dalam mengajar matematika pada mahasiswa. Salah satunya adalah pendekatan open-ended. Dalam pembelajaran dengan pendekatan open-ended, mahasiswa diberi kebebasan untuk mengeksplorasi berbagai strategi atau cara yang diyakininya untuk menyelesaikan suatu masalah. Erman Suherman (2003: 124) mengemukakan bahwa yang menjadi pokok pikiran pembelajaran dengan pendekatan openended adalah pembelajaran yang membangun kegiatan interaktif antara matematika dan mahasiswa sehingga mengundang mahasiswa untuk menjawab permasalahan melalui berbagai strategi. Masalah yang diformulasikan memiliki multi jawaban yang benar yang disebut masalah tak lengkap atau disebut juga open-ended.

Pembelajaran dengan pendekatan openended diawali dengan memberikan masalah terbuka kepada mahasiswa. Kegiatan pembelajaran harus mengarah dan membawa mahasiswa dalam menjawab masalah dengan banyak cara serta mungkin juga dengan banyak jawaban (yang benar), sehingga merangsang kemampuan intelektual dan pengalaman mahasiswa dalam proses menemukan sesuatu yang baru. Salah satu contoh pembelajaran dengan pendekatan open-ended yaitu dengan menyajikan masalah terbuka yang dapat dijadikan sebagai bahan bagi siswa untuk berpikir kreatif, misalnya: Suatu kebun yang berbentuk persegi panjang mempunyai luasnya $48 \mathrm{~m}^{2}$. Berapa ukuran panjang dan lebar kebun tersebut? Dari masalah tersebut akan dianalisis berdasarkan kreativitas mahasiswa. Jika ditinjau komponen kreativitasnya maka harus ada tiga komponen kreativitas dalam menjawab masalah tersebut yaitu dengan memperhatikan kefasihan (fluency), fleksibilitas (flexibility), dan kebaruan (originality). Kefasihan (fluency) mengacu pada banyaknya jawaban yang dibuat siswa dengan benar, seperti jawaban yang tidak sama, tetapi hal itu belum menunjukkan perbedaan dalam arti konteks maupun konsep. Jika dikaitkan dengan jawaban atas masalah di atas, maka yang mengarah pada komponen kreativitas yaitu kefasihan (fluency), contohnya: $\mathrm{p}=8 \mathrm{~m}, 1=6 \mathrm{~m} ; \mathrm{p}=4 \mathrm{~m}, \mathrm{l}=12 \mathrm{~m}$; $\mathrm{p}=3,1=16 \mathrm{~m}$. Fleksibilitas (flexibility) mengacu pada kemampuan siswa dalam menjawab masalah dengan berbagai cara yang berbeda. Jika dikaitkan dengan jawaban atas masalah di atas maka yang mengarah pada komponen kreativitas yaitu fleksibilitas (flexibility), contohnya: jika $\mathrm{p}=8 \mathrm{~m}$ maka $\mathrm{l}=48 \mathrm{~m}^{2}: 8 \mathrm{~m}=$ $6 m$; jika $l=8 m$ maka panjang $=48 m^{2}: 8 m=6 m$. Sedangkan kebaruan (originality) mengacu pada kemampuan mahasiswa menjawab masalah dengan banyak jawaban yang berbedabeda tetapi bernilai benar atau satu jawaban yang tidak biasa dibuat oleh mahasiswa pada tahap perkembangannya atau tingkat pengetahuannya, contohnya: $\mathrm{p}=12,5 \mathrm{~m}, \mathrm{l}=$ $3,84 \mathrm{~m} ; \mathrm{p}=0,4 \mathrm{dm}, \mathrm{l}=1,2 \mathrm{dm} ; \mathrm{p}=20 \mathrm{~cm}, \mathrm{l}=$ $240 \mathrm{~cm}$. 
Berkembangnya kreativitas mahasiswa selain diperngaruhi pendekatan pembelajaran juga dipengaruhi oleh motivasi belajar. Motivasi adalah suatu keadaan yang terdapat dalam diri seseorang yang menyebabkan seseorang melakukan kegiatan tertentu untuk mencapai tujuan tertentu. Dalam proses pembelajaran, motivasi merupakan salah satu aspek dinamis yang sangat penting. Motivasi belajar sangat dibutuhkan dalam proses belajarmengajar. Seperti yang diuraikan oleh Uno (2008:23) bahwa motivasi dan belajar merupakan dua hal yang sangat mempengaruhi. Motivasi belajar mahasiswa khususnya di Prodi Pendidikan Matematika FKIP UMSU dikategorikan rendah. Sering terjadi mahasiswa yang kurang berprestasi bukan disebabkan karena kemampuannya yang kurang tetapi oleh karena tidak adanya motivasi untuk belajar, sehingga mahasiswa tidak berusaha mengarahkan segala kemampuannya. Motivasi belajar tidak sama kuatnya antara mahasiswa yang satu dengan mahasiswa lainnya. Motivasi dalam diri seseorang tidak tetap, kadangkadang kuat, kadang-kadang lemah, bahkan pada suatu saat motivasi belajar dapat hilang sama sekali. Pengetahuan dan pemahaman tentang motivasi belajar mahasiswa sangat bermanfaat bagi guru untuk membangkitkan, meningkatkan dan memelihara semangat mahasiswa untuk belajar sampai berhasil.

Gambaran permasalahan-permasalahan tersebut menunjukkan bahwa pembelajaran perlu diperbaiki guna meningkatkan kemampuan berpikir kreatif mahasiswa. Hal inilah yang menjadi alasan peneliti memilih berpikir kreatif dengan menerapkan pendekatan pembelajaran open-ended.

Berdasarkan uraian di atas penulis menjadi tertarik untuk meneliti pengaruh pendekatan open-ended terhadap kemampuan berpikir kreatif siswa. Sebagai pembanding dari akibat aplikasi pembelajaran pendekatan open-ended adalah pembelajaran dengan pendekatan ekspositori.

\section{METODOLOGI PENELITIAN}

Lokasi penelitian adalah Fakultas Keguruan dan Ilmu Pendidikan Universitas Muhammadiyah Sumatera Utara Program Studi Pendidikan Matematika, dimana lokasi tersebut belum pernah dilakukan penelitian yang sejenis. Populasi dalam penelitian ini adalah mahasiswa Prodi Pendidikan Matematika FKIP UMSU semester 4 sebanyak 4 kelas dengan jumlah 110 mahasiswa. Dalam penelitian ini, peneliti mengambil sampel sebanyak 58 mahasiswa. Teknik pengambilan sampel yang digunakan adalah teknik pengambilan sampel kelompok secara acak (cluster random sampling) yaitu semua individu dalam kelas sampel menjadi subjek penelitian (Mantra dan Kasto, 1989). Dua kelas yang telah dipilih pada sekolah tersebut dibagi menjadi 1 kelas sebagai kelas eksperimen yang berjumlah 30 mahasiswa dan 1 kelas lagi menjadi kelas kontrol yang berjumlah 28 mahasiswa. Objek penelitian seluruhnya ada 58 mahasiswa. Kelas eksperimen atau kelas uji coba dalam hal ini adalah kelas yang dikenai pembelajaran dengan pendekatan open-ended dan dilakukan secara berkelompok dimana setiap masingmasing kelompok memiliki motivasi belajar tinggi, sedang dan rendah, sedangkan kelas kontrol adalah kelas yang dikenai pendekatan ekspositori dan pembelajaran dilakukan tidak secara berkelompok melainkan individu. Pengelompokan hanya dilakukan pada waktu analisis data. Demikian juga mahasiswa yang tidak terpilih menjadi sampel tetap mendapat perlakuan sama dengan sampel, namun datanya tidak ikut dianalisis. Perlakuan diberikan sebanyak 5 (lima) kali pertemuan ditambah dua kali tes yaitu tes motivasi belajar dan tes kemampuan berpikir kreatif.

Tabel 3.1. Data Sampel Penelitian

\begin{tabular}{|l|c|c|c|}
\hline \multicolumn{1}{|c|}{ Perlakuan } & \multicolumn{2}{|c|}{ SEMESTER IV } & \multirow{2}{*}{ Jumlah } \\
\cline { 2 - 3 } & A & B & 30 \\
\hline $\begin{array}{l}\text { Kelas Eksperimen } \\
\text { (Dengan Pendekatan Open-Ended) }\end{array}$ & 30 & - & 28 \\
\hline Kelas Kontrol & - & 28 & 28 \\
\hline
\end{tabular}




\begin{tabular}{|c|c|c|c|}
\hline (Tanpa Pendekatan Open-Ended) & & & \\
\hline Jumlah & 30 & 28 & 58 \\
\hline
\end{tabular}

Penelitian ini adalah penelitian kuantitatif deskriptif dengan jenis penelitian eksperimen semu (quasi experiment) dengan rancangan eksperimen desain faktorial $3 \times 2$. Kelas eksperimen diberikan perlakuan pembelajaran dengan pendekatan open-ended. Kelas kontrol diberikan perlakuan pembelajaran pendekatan ekspositori. Desain faktorial $3 \times 2$ yang digunakan dengan tujuan untuk membandingkan dua pendekatan pembelajaran yaitu pendekatan pembelajaran open-ended dan pendekatan pembelajaran ekspositori terhadap motivasi belajar tinggi, sedang dan motivasi belajar rendah. Sebelum dilaksanakan perlakuan, terlebih dahulu ditinjau faktor-faktor kesamaan dari kelas eksperimen dan kelas kontrol yaitu kesamaan dalam faktor-faktor yang mempengaruhi pelaksanaan kegiatan pembelajaran. Hal ini dilakukan dengan tujuan untuk meyakinkan kedua kelas mempunyai karakteristik yang dianggap sama.

Adapun tahap rincian prosedur perlakuan dalam penelitian ini adalah: (a) Menentukan siswa yang akan dijadikan subjek penelitian secara cluster pada mahasiswa semster IV sebanyak dua kelompok. (b) Melaksanakan perlakuan, kelompok pertama diberi perlakuan pembelajaran dengan pendekatan open-ended yaitu kelas A dan kelompok kedua diberi perlakuan pembelajaran dengan pendekatan ekspositori yaitu kelas B Khusus kelompok yang diberi perlakuan pembelajaran dengan pendekatan open-ended dibagi atas 5 kelompok, sementara kelompok yang diberi perlakuan ekspositori tidak (secara individu). (c) Perlakuan dilaksanakan sebanyak lima kali pertemuan termasuk didalamnya satu kali tes yaitu tes motivasi belajar dan tes kemampuan berpikir kreatif. Melakukan tes motivasi belajar dengan menggunakan angket. Angket yang digunakan bertujuan untuk mengetahui kecenderungan tingkat motivasi belajar siswa tiap kelompok. Lamanya waktu dalam satu kali pertemuan adalah 2 x 40 menit.

Pada tahap ini juga dilakukan ujicoba instrumen pembelajaran yaitu tes yang nantinya akan diberikan kepada subjek penelitian yaitu siswa di kelas A dan B. Ujicoba instrumen dilakukan pada mahasiswa semester VI yang telah pernah menerima pelajaran dengan pokok bahasan Segi Empat dan Segitiga.

Untuk mendapatkan kesahihan data yang diperoleh untuk digunakan dalam pengujian hipotesis penelitian maka dipandang perlu diadakan pengontrolan validitas internal dan validitas eksternal.

Data diperlukan untuk pengujian hipotesis penelitian, maka dalam hal ini perlu ditentukan teknik pengumpulan data yaitu dengan menggunakan teknik tes yaitu serangkaian pertanyaan untuk mengukur kemampuan berpikir kreatif mahasiswa dan juga angket (questionare) yaitu daftar pertanyaan/.pernyataan yang diberikan pada mahasiswa yang bersedia memberikan respon sesuai dengan keadaan yang sebenarnya untuk mengukur motivasi belajar mahasiswa.

Sebelum instrumen diujicobakan, dilakukan terlebih dahulu validasi terhadap perangkat dan instrumen oleh beberapa para ahli. Ahli yang dimaksud dalam hal ini adalah para validator yang berkompeten yang meliputi dosen. Berdasarkan hasil penelitian ahli, kemudian dilakukan revisi terhadap perangkat instrumen. Saran dari validator digunakan untuk penyempurnaan perangkat dan instrumen penelitian

Validasi perangkat difokuskan pada isi, format, bahasa dan ilustrasi serta kesesuaian pembelajaran pendekatan open-ended. Hasil validasi terhadap perangkat pembelajaran yaitu RPS (Rencana Pembelajaran Semester), Buku Mahasiswa, dan Lembar Aktivitas Mahasiswa.

Validasi perangkat difokuskan pada isi, bahasa dan ilustrasi serta kesesuian dengan pendekatan pembelajaran. Validasi instrumen penelitian dilakukan pada instrumen tes kemampuan berpikir kreatif.

Setelah dilakukan tahap validasi oleh para ahli dan revisi, maka perangkat dan instrumen siap untuk diujicobakan. Selanjutnya diadakan tahap ujicoba instrumen kepada mahasiswa yang berada di luar objek yang telah mempelajari materi Segi Empat dan Segitiga sebelumnya di semester IV. Tes ujicoba dilaksanakan di semester VI. Hal ini dimaksudkan untuk menyaring validitas butir 
soal, reliabilitas soal, daya pembeda, dan tingkat kesukaran butir soal.

Untuk melakukan analisis data digunakan teknik analisis deskriptif dan teknik analisis inferensial. Analisis statistik deskriptif yaitu untuk menggambarkan data penelitian dengan membuat daftar distribusi frekuensi dan membuat histogram. Dan dari daftar distribusi frekuensi tersebut dihitung nilai rata-rata, simpangan baku, median, modus dan varians. Analisis statistik inferensial untuk menguji hipotesis. Sebelum pengujian hipotesis dilakukan uji persyaratan yaitu uji normalitas data penelitian dengan uji Lilifors, kemudian dilanjutkan dengan uji homogenitas dengan menggunakan uji Bartlett. Untuk uji hipotesis penelitian ini digunakan teknik ANAVA $3 \times 2$ (ANAVA dua jalur) dengan uji $\mathrm{F}$ (Fisher) dengan taraf signifikansi $\alpha=0,05$.

$$
\text { Apabila hasil pengujian }
$$

menggambarkan adanya interaksi pendekatan pembelajaran maka perlu dilakukan uji lanjut. Jika jumlah tiap sel sama ( $n$ sama) maka uji

Tabel 1. Distribusi Frekuensi Kemampuan Berpikir Kreatif Mahasiswa Yang Diajar Dengan Pendekatan P embelajaran Open-Ended

\begin{tabular}{|c|c|c|c|}
\hline Kelas & Interval & Frekuensi Absolut & Frekuensi Relatif (\%) \\
\hline 1 & $6-7$ & 5 & 16,6 \\
\hline 2 & $8-9$ & 6 & 20 \\
\hline 3 & $10-11$ & 15 & 50 \\
\hline 4 & $12-13$ & 2 & 6,7 \\
\hline 5 & $14-15$ & 2 & 6,7 \\
\hline 6 & $16-17$ & 0 & 0 \\
\hline \multicolumn{2}{|l}{ Jumlah } & 30 & 100 \\
\hline
\end{tabular}

Dari tabel 1. dapat dilihat bahwa skor rata-rata berada diluar kelas interval yaitu antar kelas interval 8-9 dan 10-11 dengan jumlah mahasiswa 0. Siswa dengan skor di bawah rata-rata berjumlah 11 orang $(36.60 \%)$. Mahasiswa dengan skor di atas rata- rata berjumlah 19 orang $(63,4 \%)$. lanjut dilakukan dengan uji Tuckey dan jika jumlah sampel pada setiap sel berbeda (n berbeda) maka untuk uji lanjut menggunakan Uji Scheffe.

\section{HASIL DAN PEMBAHASAN \\ HASIL PENELITIAN
1. Kemampuan Berpikir Kreatif Mahasiswa yang Diajar dengan Pendekatan Pembelajaran Open-Ended

Hasil penelitian di lapangan menunjukkan bahwa mahasiswa yang diajar dengan pendekatan pembelajaran open-ended, memiliki skor tertinggi 15; dan skor terendah 6 ; skor rata-rata 9,83 ; median 10,03 ; modus 10,32; simpangan baku 2,12 dan varians 4,51. Distribusi frekuensi kemampuan berpikir kreatif mahasiswa yang diajar dengan pendekatan pembelajaran open ended dapat dilihat pada tabel 1 .

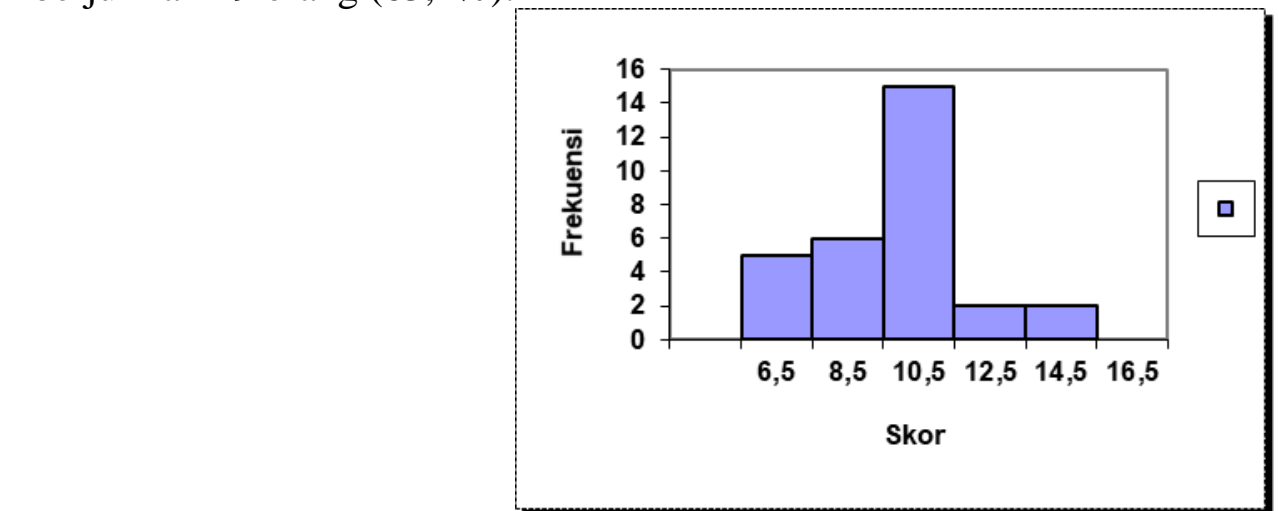

Gambar 1. Histogram Kemampuan Berpikir Kreatif Mahasiswa yang Diajar

Sebaran distribusi frekuensi skor kemampuan berpikir kreatif mahasiswa yang diajar dengan pendekatan pembelajaran open-ended dapat dilihat pada gambar 1. 
2. Kemampuan Berpikir Kreatif Mahasiswa yang Diajar dengan Pendekatan Pembelajaran Ekspositori

Hasil penelitian di lapangan menunjukan bahwa mahasiswa yang diajar dengan pendekatan pembelajaran ekspositori, memiliki skor tertinggi 13 dan skor terendah 2; skor rata - rata 6,14; median 5,75; modus 6,17; simpangan baku 3,03 dan varians 9,02. Distribusi frekuensi kemampuan berpikir kreatif mahasiswa yang diajar dengan pendekatan pembelajaran ekspositori dapat dilihat tabel 2.

Tabel 2. Distribusi Frekuensi Kemampuan Berpikir Kreatif Mahasiswa yang

Diajar Dengan Pendekatan Pembelajaran Ekspositori

\begin{tabular}{|c|c|c|c|}
\hline Kelas & Interval & Frekuensi absolut & Frekuensi relatif (\%) \\
\hline 1 & $2-3$ & 6 & 21.43 \\
\hline 2 & $4-5$ & 7 & 25 \\
\hline 3 & $6-7$ & 8 & 28.58 \\
\hline 4 & $8-9$ & 2 & 7.14 \\
\hline 5 & $10-11$ & 3 & 10.71 \\
\hline 6 & $12-13$ & 2 & 7.14 \\
\hline \multicolumn{2}{|c|}{ Jumlah } & 28 & 100.00 \\
\hline
\end{tabular}

Dari tabel 2. dapat dilihat bahwa skor rata-rata berada pada kelas interval, yaitu kelas interval 6-7 dengan jumlah mahasiswa berarti 8 orang $(28,58 \%)$. Mahasiswa dengan skor di bawah rata-rata berjumlah 13 orang $(46,43 \%)$. Mahasiswa dengan skor di atas rata-rata berjumlah 7 orang $(24,99 \%)$.
Sebaran distribusi frekuensi skor kemampuan berpikir kreatif mahasiswa yang diajar dengan pendekatan pembelajaran ekspositori dapat dilihat pada gambar 2 .

Gambar 2. Histogram Kemampuan Berpikir Kreatif yang Diajar dengan

Pendekatan Pembelajaran Ekspositori

\section{Kemampuan Berpikir Kreatif Mahasiswa yang Memiliki Motivasi Belajar Tinggi}

Hasil penelitian di lapangan menunjukkan bahwa mahasiswa yang memiliki motivasi belajar tinggi memiliki skor tertinggi
15 dan skor terendah 10; skor rata-rata 12,22 ; median 12; modus 12; simpangan baku 1,47 dan varians 2,17. Distribusi frekuensi kemampuan berpikir kreatif mahasiswa yang memiliki motivasi belajar tinggi dapat dilihat pada tabel 3 .

Tabel 3. Distribusi Frekuensi Kemampuan Berpikir Kreatif Mahasiswa Yang Memiliki Motivasi Belajar Tinggi

\begin{tabular}{|c|c|c|c|}
\hline Kelas & Nilai & $\begin{array}{c}\text { Frekuensi } \\
\text { Absolut }\end{array}$ & $\begin{array}{c}\text { Frekuensi Relatif } \\
(\%)\end{array}$ \\
\hline 1 & 10 & 1 & 11,11 \\
\hline 2 & 11 & 2 & 22,23 \\
\hline 3 & 12 & 3 & 33,33 \\
\hline 4 & 13 & 1 & 11,11 \\
\hline
\end{tabular}




\begin{tabular}{|c|c|c|c|}
\hline 5 & 14 & 1 & 11,11 \\
\hline 6 & 15 & 1 & 11,11 \\
\hline \multicolumn{2}{|c|}{ Jumlah } & 9 & 100 \\
\hline
\end{tabular}

Dari tabel 3. dapat dilihat bahwa skor rata-rata berada pada kelas 3 dengan jumlah siswa $3(33,33 \%)$. Mahasiswa dengan skor di bawah rata-rata berjumlah 3 orang $(33,34 \%)$. Mahasiswa dengan skor di atas rata-rata berjumlah 3 orang $(33,33 \%)$.
Sebaran distribusi frekuensi skor kemampuan berpikir kreatif mahasiswa yang memiliki motivasi belajar tinggi dilihat pada gambar 3.

Gambar 3. Histogram Kemampuan Berpikir Kreatif Mahasiswa yang Memiliki Motivasi Belajar Tinggi

\section{Kemampuan Berpikir Kreatif Mahasiswa} yang Memiliki Motivasi Belajar Sedang

Hasil penelitian di lapangan menunjukkan bahwa mahasiswa yang memiliki motivasi belajar tinggi memiliki skor tertinggi 11 dan skor terendah 4; skor rata-rata 8,13 ; median 10; modus 10; simpangan baku 2,33 dan varians 5,43. Distribusi frekuensi kemampuan berpikir kreatif siswa yang memiliki motivasi belajar tinggi dapat dilihat pada tabel 4.

Tabel 4. Distribusi Frekuensi Kemampuan Berpikir Kreatif Mahasiswa Yang Memiliki Motivasi Belajar Sedang

\begin{tabular}{|c|c|c|c|}
\hline Kelas & Nilai & $\begin{array}{c}\text { Frekuensi } \\
\text { Absolut }\end{array}$ & Frekuensi Relatif (\%) \\
\hline 1 & 4 & 3 & 7,89 \\
\hline 2 & 5 & 4 & 10,54 \\
\hline 3 & 6 & 5 & 13,16 \\
\hline 4 & 7 & 3 & 7,89 \\
\hline 5 & 8 & 3 & 7,89 \\
\hline 6 & 9 & 5 & 13,16 \\
\hline 7 & 10 & 8 & 21,05 \\
\hline 8 & 11 & 7 & 18,42 \\
\hline \multicolumn{2}{|r|}{ Jumlah } & 38 & 100 \\
\hline
\end{tabular}

Dari tabel 4. dapat dilihat bahwa skor rata-rata berada pada kelas 5 dengan jumlah mahasiswa $3(7,89 \%)$. Mahasiswa dengan skor di bawah rata-rata berjumlah 15 orang $(39,48 \%)$. Mahasiswa dengan skor di atas ratarata berjumlah 20 orang $(52,63 \%)$.
Sebaran distribusi frekuensi skor kemampuan berpikir kreatif mahasiswa yang memiliki motivasi belajar sedang dilihat pada gambar 4. 


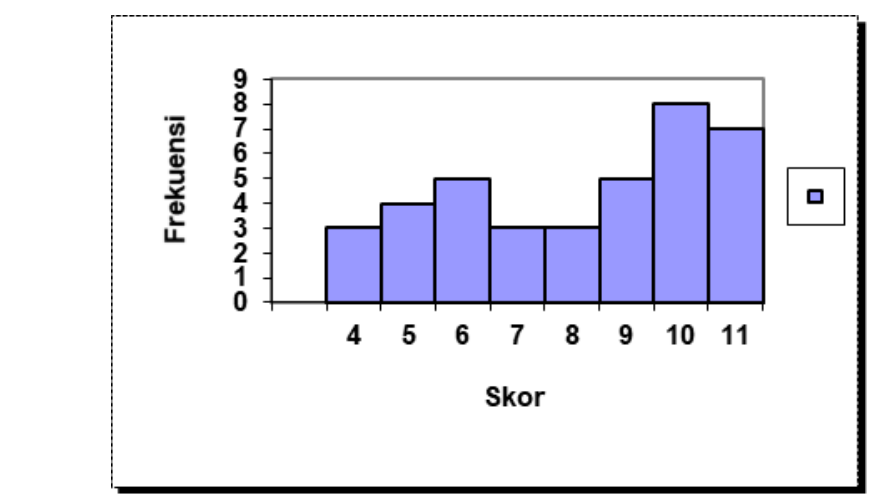

Gambar 4. Histogram Kemampuan Berpikir Kreatif Mahasiswa yang Memiliki Motivasi Belajar Sedang

\section{Kemampuan Berpikir Kreatif Mahasiswa yang Memiliki Motivasi Belajar Rendah}

Hasil penelitian dilapangan menunjukkan bahwa siswa yang memiliki motivasi belajar rendah, memiliki skor tertinggi
7 dan skor terendah 2; skor rata-rata 4,45; median 3; modus 7; simpangan baku 2,19; dan varians 4,79. Distribusi frekuensi kemampuan berpikir kreatif mahasiswa yang memiliki motivasi belajar rendah dapat dilihat pada tabel 5 .

Tabel 5. Distribusi Frekuensi Kemampuan Berpikir Kreatif mahasiswa yang Memiliki Motivasi Belajar Rendah

\begin{tabular}{|c|c|c|c|}
\hline Kelas & Nilai & Frekuensi Absolut & Frekuensi Relatif (\%) \\
\hline 1 & 2 & 3 & 27,27 \\
\hline 2 & 3 & 3 & 27,27 \\
\hline 3 & 6 & 1 & 9,09 \\
\hline 4 & 7 & 4 & 36,37 \\
\hline \multicolumn{2}{|c|}{ Jumlah } & 11 & 100 \\
\hline
\end{tabular}

Dari tabel 5. dapat dilihat bahwa skor rata-rata berada di kelas ke-3 dengan jumlah mahasiswa 3 orang $(27,27 \%)$. Siswa dengan skor dibawah rata-rata berjumlah 3 orang $(22,27 \%)$. Mahasiswa dengan skor di atas ratarata berjumlah 5 orang $(45,46 \%)$.
Sebaran distribusi frekuensi skor kemampuan berpikir kreatif mahasiswa yang memiliki motivasi belajar rendah dilihat pada gambar 5.

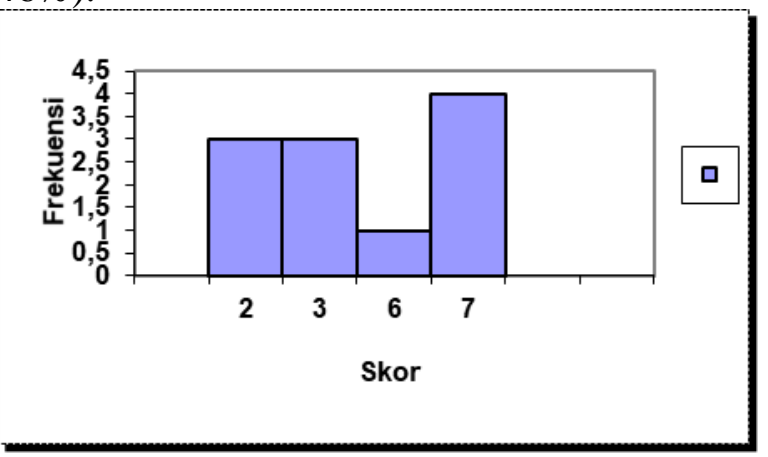

Gambar 5 Histogram Kemampuan Berpikir Kreatif Mahasiswa Yang Memiliki Motivasi Belajar Rendah

Berdasarkan paparan data di atas, terlihat bahwa ukuran sampel dari tiap kelompok data tidaklah sama. Sehingga perlu dilakukan tes homogenitas variansi. Menurut Ruseffendi (1998:272) menyatakan bahwa homogenitas variansi dari dua populasi dibandingkan bila besarnya ukuran-ukuran sampel itu kecil atau tidak sama. Kemudian besar atau kecilnya ukuran sampel dari tiap kelompok data harus berasal dari populasi yang berdistribusi normal. Untuk memastikan bahwa tiap kelompok data berdistribusi normal, perlu dilakukan uji normalitas. Perhitungan uji homogenitas dan uji normalitas ini diperlukan karena dalam penelitian ini menggunakan teknik-teknik statistik inferensi, yang syarat- 
syaratnya data harus berdistribusi normal dan homogen.

Uji persyaratan analisis bertujuan untuk menguji data yang diperoleh sebelum dilakukan analisis statistik yang telah ditentukan. Uji persyaratan analisis digunakan untuk pemeriksaan awal mengenai asumsiasumsi agar pengujian dengan analisis varians dapat dilakukan. Uji persyaratan analisis meliputi uji normalitas data dengan menggunakan Liliefors dan uji homogenitas dengan menggunakan uji Bartlett.

\section{Uji Normalitas Data}

Uji normalitas bertujuan untuk melihat apakah skor kemampuan berpikir kreatif mahasiswa untuk setiap kelompok terdistribusi secara normal. Berdasarkan hasil pengujian dengan uji Liliefors (Lampiran L), diperoleh data untuk tiap kelompok pengujian sebagai berikut:

Tabel 6. Ringkasan Hasil Uji Normalitas Sampel Dengan Uji Liliefors $(\alpha=0,05)$

\begin{tabular}{|c|c|c|c|c|}
\hline $\begin{array}{c}\text { Kelompok } \\
\text { Sampel }\end{array}$ & $\mathbf{N}$ & $\mathbf{L}_{\mathbf{o}}$ & $\begin{array}{c}\text { Tabel Liliefors } \\
(\boldsymbol{\alpha}=\mathbf{0 . 0 5})\end{array}$ & Keterangan \\
\hline $\mathrm{A}_{1}$ & 30 & 0,1348 & 0,161 & Normal \\
\hline $\mathrm{A}_{2}$ & 28 & 0,1349 & 0,166 & Normal \\
\hline $\mathrm{B}_{1}$ & 9 & 0,1156 & 0,271 & Normal \\
\hline $\mathrm{B}_{2}$ & 38 & 0,132 & 0,1437 & Normal \\
\hline $\mathrm{B}_{3}$ & 11 & 0,1902 & 0,249 & Normal \\
\hline $\mathrm{A}_{1} \mathrm{~B}_{1}$ & 4 & 0,1517 & 0,381 & Normal \\
\hline $\mathrm{A}_{1} \mathrm{~B}_{2}$ & 21 & 0,1667 & 0,187 & Normal \\
\hline $\mathrm{A}_{1} \mathrm{~B}_{3}$ & 5 & 0,33 & 0,337 & Normal \\
\hline $\mathrm{A}_{2} \mathrm{~B}_{1}$ & 5 & 0,1948 & 0,337 & Normal \\
\hline $\mathrm{A}_{2} \mathrm{~B}_{2}$ & 17 & 0,1507 & 0,206 & Normal \\
\hline $\mathrm{A}_{2} \mathrm{~B}_{3}$ & 6 & 0,3186 & 0,319 & \\
\hline
\end{tabular}

Berdasarkan tabel 6. dapat dilihat bahwa harga Lo dari setiap kelompok perlakuan lebih kecil dari harga $\mathrm{L}_{\text {tabel. }}$ Sehingga dapat disimpulkan bahwa skor kemampuan berpikir kritis mahasiswa untuk setiap kelompok berdistribusi normal.
Sebaran data skor kemampuan berpikir kreatif dari setiap kelompok sampel dengan menggunakan SPSS versi 20.00 dapat dilihat pada gambar 6 . berikut:

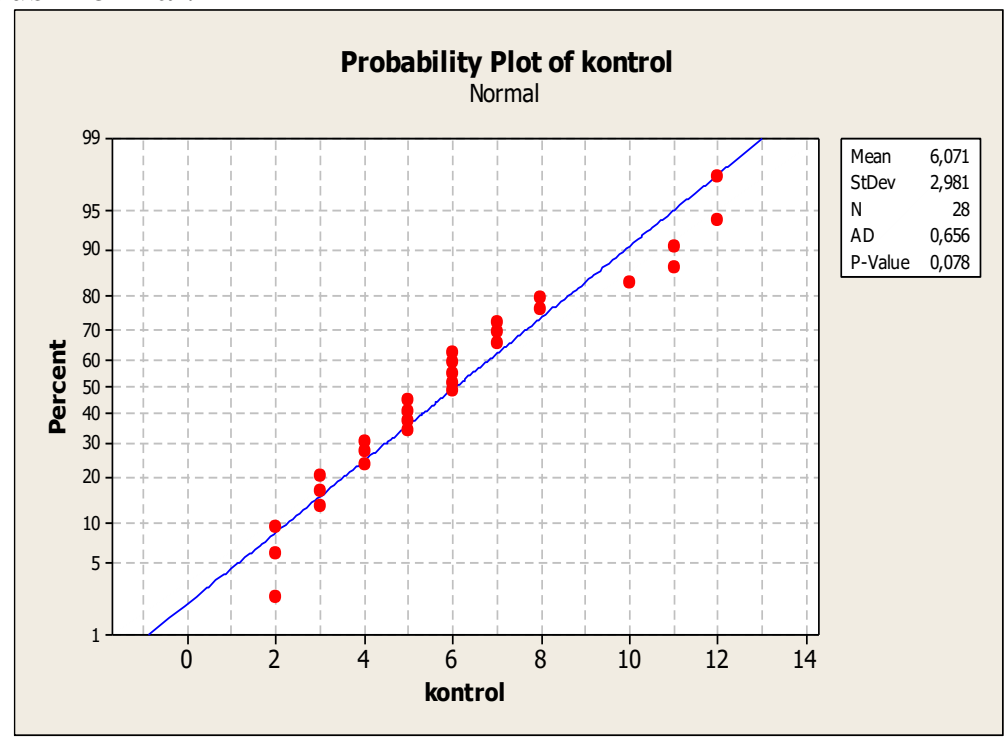

Gambar 6. Plot Kemampuan Berpikir Kreatif Kelas Kontrol

Kriteria keputusan: Jika $\mathrm{P}$ value $<$ alpha $=0,05$

Hipotesis:

$\mathrm{H}_{0}$ : data menyebar secara normal

$\mathrm{H}_{1}$ : data tidak menyebar secara normal maka tolak $\mathrm{H}_{0}$, sebaliknya jika $\mathrm{P}$ value > alpha $=0,05$ maka terima $\mathrm{H}_{0}$. 
Interpretasi:

Hasil analisis uji normalitas menyebutkan data menyebar secara normal, hal ini ditunjukkan dengan nilai $\mathrm{P}$ value $=0,078>$ alpha $=0,05$.

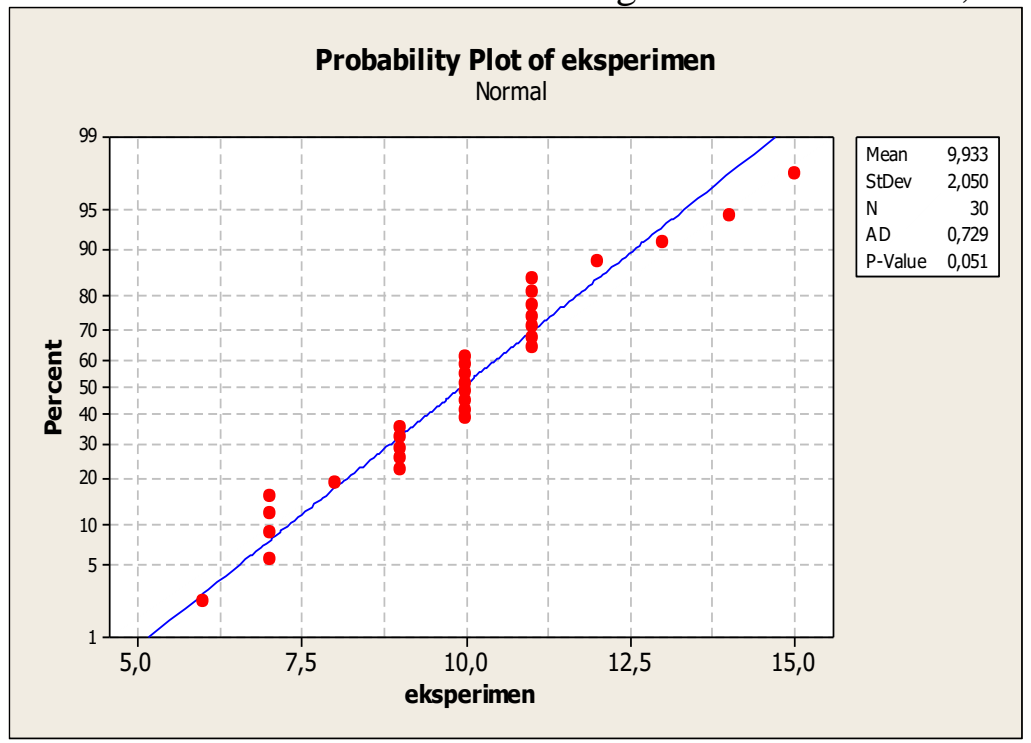

Gambar 7. Plot Kemampuan Berpikir Kreatif Kelas Eksperimen

Hipotesis:

$\mathrm{H}_{0}$ : data menyebar secara normal

$\mathrm{H}_{1}$ : data tidak menyebar secara normal

Kriteria keputusan: Jika $\mathrm{P}$ value $<$ alpha $=0,05$ maka tolak $\mathrm{H}_{0}$, sebaliknya jika $\mathrm{P}$ value $>$ alpha $=0,05$ maka terima $\mathrm{H}_{0}$.

Interpretasi:

Hasil analisis uji normalitas menyebutkan data menyebar secara normal, hal ini ditunjukkan dengan nilai $\mathrm{P}$ value $=0,051>$ alpha $=0,05$.

Setelah dilakukan pengujian terhadap normalitas data, maka pengujian tahap selanjutnya adalah homogenitas varians.

\section{Uji Homogenitas Varians}

Untuk mengetahui homogenitas varians populasi antar kelompok yang dibandingkan digunakan 2 jenis pengujian. Kelompok data pendekatan pembelajaran dan motivasi belajar menggunakan uji varians terbesar dibanding varians terkecil. Uji digunakan karena membandingkan 2 kelompok perlakuan. Uji Bartlett digunakan untuk kelompok masingmasing perlakuan, karena membandingkan lebih dari dua kelompok perlakuan. Pengujian ini bertujuan untuk melihat apakah populasi penelitian dari setiap kelompok bersifat homogen.

Dari perhitungan pengujian homogenitas populasi di peroleh hasil sebagai berikut:

\section{a. Kelompok Pendekatan Pembelajaran}

Hasil perhitungan untuk kelompok data pendekatan pembelajaran ditunjukkan pada tabel 7. berikut:

Tabel 7. Ringkasan Uji Homogenitas Kelompok Data Pendekatan Pembelajaran

\begin{tabular}{|c|c|c|c|c|c|}
\hline $\mathrm{S}^{2}$ Gabungan & $\mathrm{B}$ & $\mathrm{Dk}$ & $\chi^{2}$ hitung & $\chi^{2}$ tabel & Kesimpulan \\
\hline 6,77 & 46,48 & 56 & 3,42 & 79,10 & Homogen \\
\hline
\end{tabular}

Dari hasil perhitungan dapat dilihat bahwa $\chi^{2}$ hitung $=3,42$ lebih kecil dari $\chi^{2}$ tabel $\alpha$ $=(5 \%)=79,10 \quad$ Sehingga dapat disimpulkan bahwa data skor kelompok pendekatan pembelajaran memiliki variansi populasi yang homogen.

\section{b. Kelompok Motivasi Belajar}

Hasil perhitungan untuk kelompok data motivasi belajar ditunjukan pada tabel 8 . berikut:

Tabel 8. Ringkasan Uji Homogenitas Kelompok Data Motivasi Belajar

\begin{tabular}{|c|c|c|c|c|c|}
\hline $\mathrm{S}^{2}$ Gabungan & $\mathrm{B}$ & $\mathrm{Dk}$ & $\chi^{2}$ hitung & $\chi^{2}$ tabel & Kesimpulan \\
\hline
\end{tabular}




\begin{tabular}{|l|c|c|c|c|c|}
\hline 4,84 & 37,67 & 55 & 2,23 & 79,10 & Homogen \\
\hline
\end{tabular}

Dari hasil perhitungan terlihat bahwa $\chi^{2}$ hitung $<\chi^{2}$ tabel atau $2,23<79,10$. Hal ini berarti bahwa sampel yang diambil pada penelitian ini berasal dari populasi yang homogen.

Tabel 9. Hasil Pengujian Homogenitas Varians Populasi Dengan Uji Barlett

\begin{tabular}{|c|c|c|c|c|c|}
\hline $\mathrm{S}^{2}$ Gabungan & $\mathrm{B}$ & $\mathrm{Dk}$ & $\chi^{2}$ hitung & $\chi^{2}$ tabel & Kesimpulan \\
\hline 2,55 & 21,11 & 52 & $-12,99$ & 79,10 & Homogen \\
\hline
\end{tabular}

Dari hasil perhitungan manual terlihat bahwa $\chi^{2}$ hitung $<\chi^{2}$ tabel atau $-12,99<79,10$. Hal ini berarti bahwa sampel yang diambil pada penelitian ini berasal dari populasi yang homogen.

\section{c. Kelompok Data Masing - Masing Perlakuan}

Selanjutnya hasil perhitungan varians gabungan dirangkum dalam tabel 9. berikut:

Sebaran data skor kemampuan berpikir kreatif dari setiap kelompok sampel dapat dilihat pada gambar 8 . berikut:

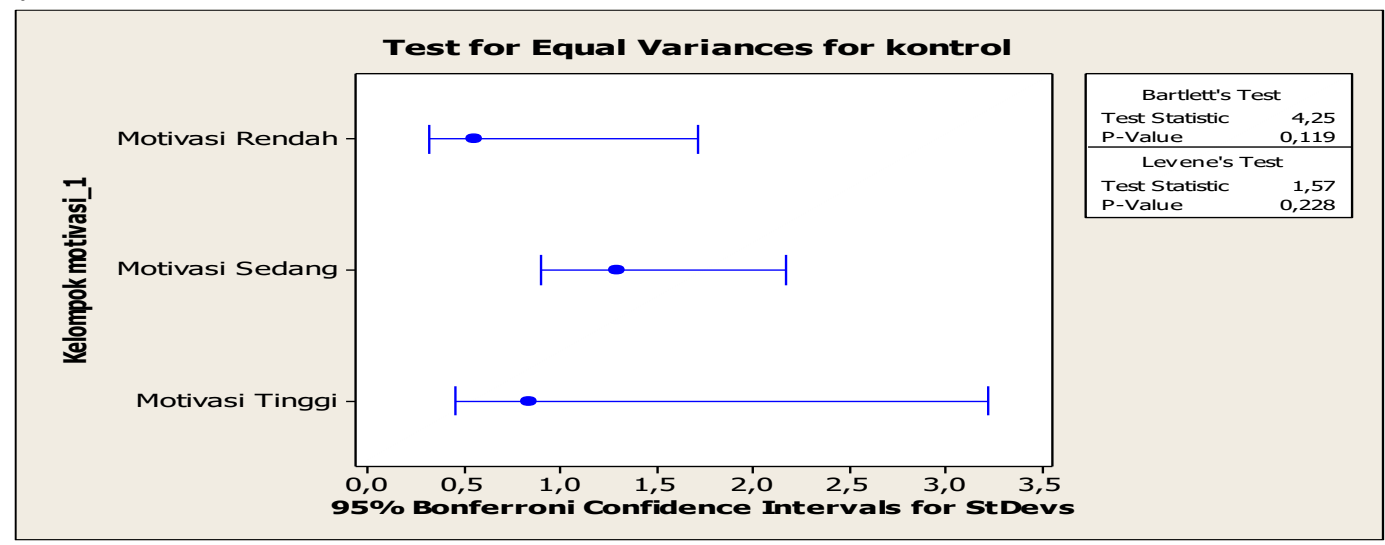

Gambar 8. Sebaran Data Skor Kemampuan Berpikir Kreatif Kelas Kontrol Ditinjau Dari Motivasi Belajar

Hipotesis:

$\mathrm{H}_{0}$ : varians kelompok data homogen

$\mathrm{H}_{1}$ : varians kelompok data tidak homogen

Kriteria keputusan: Jika $\mathrm{P}$ value $<$ alpha $=0,05$ maka tolak $\mathrm{H}_{0}$, sebaliknya jika $\mathrm{P}$ value $>$ alpha $=0,05$ maka terima $\mathrm{H}_{0}$.
Interpretasi:

Hasil analisis uji homogenitas varians menyebutkan varians kelompok data homogen, hal ini ditunjukkan dengan nilai $\mathrm{P}$ value $=$ $0,228>$ alpha $=0,05$.

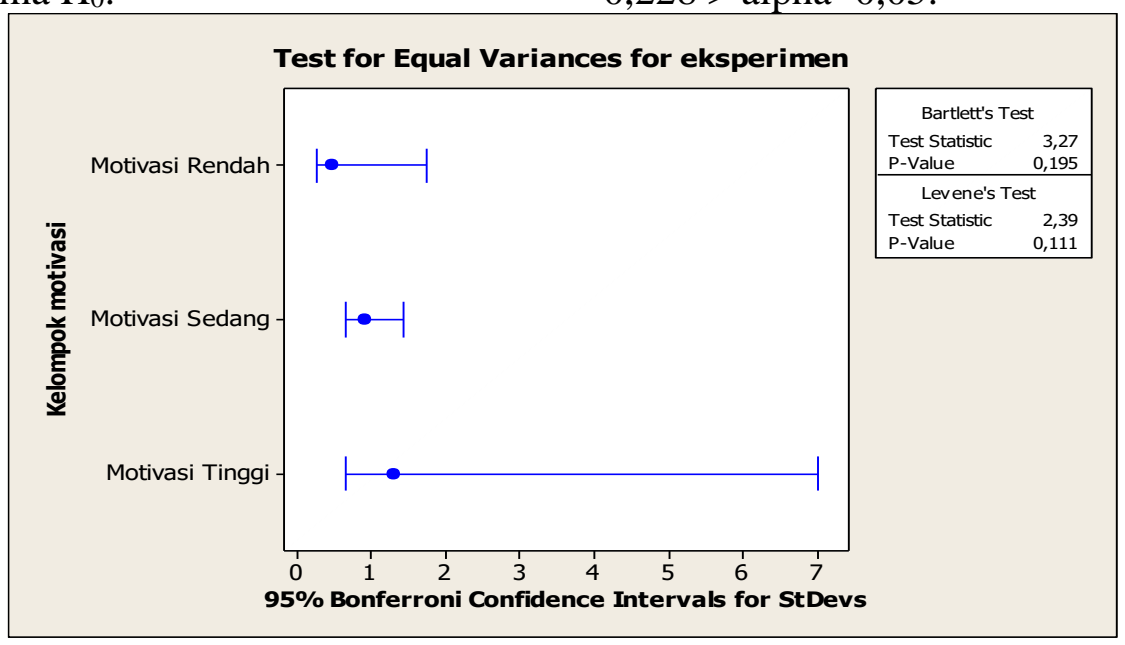

Gambar 9. Sebaran Data Skor Kemampuan Brepikir Kreatif Kelas 
Hipotesis:

$\mathrm{H}_{0}$ : varians kelompok data homogen

$\mathrm{H}_{1}$ : varians kelompok data tidak homogen

Kriteria keputusan: Jika $\mathrm{P}$ value $<$ alpha $=0,05$

maka tolak $\mathrm{H} 0$, sebaliknya jika $\mathrm{P}$ value $>$ alpha $=0,05$ maka terima $\mathrm{H}_{0}$.

Interpretasi:

Hasil analisis uji homogenitas varians menyebutkan varians kelompok data homogen, hal ini ditunjukkan dengan nilai $\mathrm{P}$ value $=0,111$ $>$ alpha $=0,05$.

Sampel penelitian secara keseluruhan memiliki data yang berdistribusi normal dan populasi yang homogen. Dengan demikian uji prasyarat analisis telah dipenuhi, dan dilanjutkan pengujian hipotesis menggunakan ANAVA dua jalur.

\section{Pengujian Hipotesis}

Pengujian hipotesis penelitian dilakukan dengan menggunakan Anava 3 x 2, untuk keperluan pengujian hipotesis diperlukan tabel pembantu perhitungan sebagai berikut: secara keseluruhan tabel anava dua jalur untuk pengujian hipotesis dapat dilihat pada tabel 4.16.

Tabel 10. Ringkasan Hasil Perhitungan Anava Dua Jalur

Tests of Between-Subjects Effects

Dependent Variable: Kemampuan Berpikir Kreatif

\begin{tabular}{|l|r|r|r|r|r|}
\hline Source & $\begin{array}{c}\text { Type III Sum } \\
\text { of Squares }\end{array}$ & \multicolumn{1}{c|}{ df } & Mean Square & \multicolumn{1}{c|}{ F } & Sig. \\
\hline Corrected Model & $525,154^{\mathrm{a}}$ & 5 & 105,031 & 103,891 &, 000 \\
Intercept & 2689,155 & 1 & 2689,155 & 2659,968 &, 000 \\
Motivasi & 290,895 & 2 & 145,447 & 143,869 &, 000 \\
Metode & 125,806 & 1 & 125,806 & 124,440 &, 000 \\
Pembelajaran & 6,842 & 2 & 3,421 & 3,384 &, 042 \\
Interaksi & 52,571 & 52 & 1,011 & & \\
Error & 4354,000 & 58 & & & \\
Total & 577,724 & 57 & & & \\
Corrected Total & & & & \\
\hline
\end{tabular}

a. R Squared $=, 909$ (Adjusted R Squared $=, 900)$

Berdasarkan tabel di atas berikut akan diuraikan mengenai uji hipotesis:

Hipotesis 1: Kemampuan berpikir kreatif siswa yang diajar dengan pendekatan open-ended lebih baik dari pada kemampuan berpikir kreatif mahasiswa yang diajar dengan pembelajaran ekspositori.

Pengujian dilakukan terhadap hipotesis statistik berdasarkan uji anava yang dirumuskan sebagai berikut:

Ho $: \mu A_{1}=\mu A_{2}$

Tidak terdapat perbedaan kemampuan berpikir kreatif mahasiswa yang diajar dengan pendekatan open-ended dibandingkan mahasiswa yang diajar dengan pembelajaran ekspositori.

$\mathrm{H}_{1}: \mu \mathrm{A}_{1}>\mu \mathrm{A}_{2}$

Terdapat perbedaan kemampuan berpikir kreatif mahasiswa yang diajar dengan pendekatan open-ended dibandingkan mahasiswa yang diajar dengan pembelajaran ekspositori.
Berdasarkan hasil pengujian hipotesis pada tabel 10, diperoleh hasil perhitungan data dimana $F_{\text {hitung }}=124,44$ dan nilai kritik $F_{\text {tabel }}$ pada taraf signifikan 0,05 adalah 4,01 hasil ini menunjukkan bahwa $\mathrm{F}_{\text {hitung }}=124,44>\mathrm{F}_{\text {tabel }}=$ 4,01 sehingga hipotesis nol (Ho) ditolak, dengan demikian hipotesis penelitian yang menyatakan bahwa kemampuan berpikir kreatif mahasiswa yang diajar dengan pendekatan open-ended berbeda dari mahasiswa yang diajar dengan pendekatan pembelajaran ekspositori, diterima. Artinya pembelajaran pendekatan open-ended lebih baik dari pada pembelajaran ekspositori, hal ini dapat juga dilihat dari nilai signifikansi 0.000 lebih kecil dari nilai taraf signifikan 0,05 , maka tolak Ho dan terima $\mathrm{H}_{1}$. Dengan demikian hipotesis 1 telah teruji kebenarannya.

Hipotesis 2: Ada perbedaan kemampuan berpikir kreatif mahasiswa yang memiliki motivasi belajar tinggi, sedang dan rendah. 
Pengujian dilakukan terhadap hipotesis statistik berdasarkan uji anava yang dirumuskan sebagai berikut:

Ho: $\mu B_{1}=\mu B_{2}=\mu B_{3}$

Tidak terdapat perbedaan kemampuan berpikir kreatif mahasiswa yang memiliki motivasi belajar tinggi, sedang dan rendah.

$\mathrm{H}_{1}: \mu B_{1}>\mu B_{2}>\mu B_{3}$

Terdapat perbedaan kemampuan berpikir kreatif mahasiswa yang memiliki motivasi belajar tinggi, sedang dan rendah.

Bedasarkan hasil pengujian hipotesis pada tabel 10, diperoleh hasil perhitungan data dimana $F_{\text {hitung }}=143,869$ dan nilai titik $F_{\text {tabel }}$ pada taraf signifikan 0,05 adalah 3,16 . hasil menunujukan bahwa $F_{\text {hitung }}=143,869>F_{\text {tabel }}=$ 3,16 sehingga hipotesis nol (Ho) ditolak, dengan demikian hipotesis penelitian yang menyatakan bahwa terdapat perbedaan kemampuan berpikir kreatif mahasiswa yang memiliki motivasi belajar tinggi, sedang dan rendah diterima. Artinya kemampuan berpikir kreatif mahasiswa yang memiliki motivasi belajar tinggi lebih baik dari siswa yang memiliki motivasi belajar sedang maupun motivasi belajar rendah, hal ini dapat juga dilihat dari nilai signifikansi 0.000 lebih kecil dari nilai taraf signifikan 0,05, maka tolak Ho dan terima $\mathrm{H}_{1}$. Dengan demikian hipotesis 2 telah teruji kebenarannya.

\section{PEMBAHASAN HASIL PENELITIAN}

Pada bagian ini akan diuraikan deskripsi dan interpretasikan data hasil penelitian. Deskripsi dan interpretasi dilakukan terhadap kemampuan berpikir kreatif dalam proses pembelajaran terkait dengan hipotesis penelitian. Berdasarkan pengumpulan data yang dilakukan selama pelaksanaan penelitian di Prodi Pendidikan Matematika FKIP UMSU dan analisis data penelitian diperoleh beberapa hasil penelitian sebagai berikut:

1. Perbedaan Kemampuan Berpikir Kreatif Antara Kelompok Mahasiswa yang Diajar Dengan Pendekatan Open-Ended Dengan Kelompok Mahasiswa yang Diajar Dengan Pendekatan Ekspositori

Hasil pengujian hipotesis pertama membuktikan bahwa kemampuan berpikir kreatif mahasiswa pada kedua perlakuan memberikan perbedaan yang signifikan. Secara keseluruhan mahasiswa yang belajar dengan pendekatan open-ended lebih tinggi hasilnya dibandingkan dengan mahasiswa yang belajar dengan pendekatan ekspositori. Dan melalui uji lanjut terbukti bahwa kemampuan berpikir kreatif mahasiswa yang diajar dengan pendekatan open-ended lebih tinggi dibandingkan dengan mahasiswa yang diajar dengan pendekatan ekspositori. Dalam hal ini dapat dinyatakan bahwa untuk mencapai tujuan (atau kompetensi dasar), pembelajaran dengan pendekatan open-ended lebih efektif dibanding dengan pembelajaran dengan pendekatan ekspositori.

Dan teori belajar Piaget salah satu teori belajar yang mendasari pandangan ini menyatakan bahwa pengetahuan terbentuk berdasarkan keaktifan orang itu sendiri dalam berhadapan dengan persoalan, bahan, atau lingkungan baru (Suparno, 2006: 36)

\section{Efektifitas pendekatan open-ended} terhadap kemampuan berpikir kreatif mahasiswa, tidak terlepas dari peranan dosen dan mahasiswa itu sendiri. Peranan dosen dalam pembelajaran seperti: membagi mahasiswa dalam kelompok kecil, menjelaskan materi secara ringkas, membuat LAM dan membuat buku mahasiswa serta menyajikan masalah terbuka. Sejalan dengan teori "Dengan adanya tipe soal tebuka (soal-soal open-ended) dosen berpeluang untuk membantu mahasiswa dalam memahami dan mengelaborasi ide-ide matematika mahasiswa sejauh dan sedalam mungkin" (Nohda, 2000: 41). Kegiatan dosen menurut Shimada (1997: 1) dalam pembelajaran open ended adalah mendorong mahasiswa untuk dapat menyajikan suatu permasalahan yang memiliki lebih dari satu jawaban atau metoda penyelesaian. Menurut Shimada pendekatan ini memberi mahasiswa kesempatan untuk memperoleh pengetahuan, pengalaman menemukan, mengenali dan memecahkan masalah dengan beberapa cara berbeda.

Sedangkan peranan mahasiswa dapat dilihat sewaktu belajar. Teori belajar Piaqet salah satu teori belajar yang mendasari pandangan ini menyatakan bahwa pengetahuan terbentuk berdasarkan keaktifan orang itu sendiri dalam berhadapan dengan persoalan, 
bahan, atau lingkungan baru (Suparno, 2006: 36).

Menurut Gagne (Tim MKPBM,2001: 35), dalam belajar matematika ada dua objek yang dapat diperoleh mahasiswa, yaitu objek langsung dan objek tak langsung. Objek tak langsung antara lain kemampuan menyelidiki dan memecahkan masalah, belajar mandiri, bersikap positif terhadap matematika, dan tahu bagaimana semestinya belajar. Sedangkan objek langsung berupa fakta, ketrampilan, konsep, dan aturan. Teori belajar Bruner (Dahar, 1989) menganjurkan agar mahasiswa sebaiknya melakukan belajar penemuan (discovery learning). Belajar penemuan dilakukan atas dasar usaha sendiri dalam melakukan pemecahan masalah serta mahasiswa memakai pengetahuan yang dia miliki. Selain membangkitkan keingintahuan, penemuan juga memberi motivasi untuk bekerja terus sampai menemukan jawabanjawaban. Secara teori pendekatan open-ended lebih baik dari pendekatan ekpositori, dan dari data empiris pada penelitian ini juga memperkuat teori tersebut.

Secara teori pendekatan open-ended lebih baik dari pendekatan ekpositori, dan dari data empiris pada penelitian ini juga memperkuat teori tersebut. Jadi, dalam pembelajaran dengan pendekatan open-ended cukup signifikan bagi mahasiswa Pendidikan Matematika FKIP UMSU dalam mengembangkan kemampuan berpikir kreatifnya, khususnya kompetensi memahami materi Segi Empat dan Segitiga. Dan hal ini sangat relevan dengan penelitian Enden Mina (2006) terhadap siswa kelas 2 SMA Negeri 12 Bandung yang menunjukkan bahwa kemampuan berpikir kreatif matematik siswa yang memperoleh pembelajaran dengan pendekatan open-ended lebih baik dari pada kemampuan kreatif matematik siswa yang memperoleh pembelajaran biasa.

2. Perbedaan Kemampuan Berpikir Kreatif Mahasiswa yang Memiliki Motivasi Belajar Tinggi, Sedang dan Rendah

Hasil pengujian hipotesis kedua, membuktikan bahwa secara keseluruhan mahasiswa yang memiliki motivasi belajar tinggi lebih baik hasilnya dibandingkan dengan mahasiswa yang memiliki motivasi sedang dan rendah. Dalam hal ini dapat dinyatakan bahwa untuk mencapai tujuan (atau kompetensi dasar), mahasiswa yang memiliki motivasi belajar tinggi lebih efektif dibanding dengan mahasiswa yang memiliki motivasi belajar sedang dan motivasi belajar rendah.

Pengaruh motivasi dalam pembelajaran terhadap kemampuan berpikir kreatif, tidak terlepas dari dorongan yang ada dalam diri mahasiswa. Faktor yang mempengaruhi dorongan tersebut diantaranya: cita-cita atau aspirasi mahasiswa, kemampuan mahasiswa, kondisi mahasiswa, kondisi lingkungan mahasiswa dan unsur-unsur lainnya seperti pengalaman mahasiswa, media belajar, dan peran dosen dalam pembelajaran.

Teori belajar Bruner (Dahar, 1989) menyatakan bahawa untuk dapat membangkitkan keingintahuan dan juga memberi motivasi untuk bekerja terus sampai menemukan jawaban sebaiknya melakukan belajar penemuan (discovery learning). Belajar penemuan terkait dengan kemampuan berpikir kreatif mahasiswa. Belajar penemuan dilakukan atas dasar usaha sendiri dalam melakukan pemecahan masalah serta mahasiswa memakai pengetahuan yang dia miliki. Oleh karena mahasiswa semakin banyak melibatkan konsep-konsep dan prinsip-prinsip, maka dia dapat memperoleh pengalaman untuk melakukan penemuan-penemuan

\section{SIMPULAN}

Berdasarkan hasil pengujian hipotesis berikut pembahasannya dapat disimpulkan bahwa:

1. Secara keseluruhan ada perbedaan kemampuan berpikir kreatif mahasiswa yang diajar dengan pendekatan open-ended dengan kemampuan berpikir kreatif mahasiswa yang diajarkan dengan pendekatan ekspositori. Kemampuan berpikir kreatif mahasiswa yang diajar dengan pendekatan open-ended lebih baik dibandingkan dengan kemampuan bepikir kreatif mahasiswa yang diajar dengan pendekatan ekspositori. Hal ini menunjukkan adanya pengaruh pembelajaran dengan pendekatan openended terhadap kemampuan berpikir kreatif mahasiswa.

2. Kemampuan berpikir kreatif mahasiswa yang memiliki motivasi tinggi lebih tinggi 
dibandingkan dengan kemampuan berpikir kreatif mahasiswa yang memiliki motivasi belajar sedang dan rendah. Hal ini menujukkan adanya pengaruh motivasi belajar terhadap kemampuan berpikir kreatif mahasiswa.

\section{SARAN}

Berdasarkan simpulan dan implikasi penelitian, maka penulis ingin mengemukakan beberapa saran sebagai berikut:

1. Para Dosen, guru, khususnya dosen dan guru matematika, hendaknya dalam memberikan pembelajaran dengan menggunakan pendekatan open-ended benar-benar memahami langkah-langkah pembelajaran dengan pendekatan openended. Oleh karena itu diperlukan pemberian pengarahan dan rancangan dan bahan perlakuan terhadapa mahasiswa atau siswa karena pendekatan pembelajaran ini menyajikan suatu permasalahan yang memiliki lebih dari satu jawaban atau metoda penyelesaian sehingga mahasiswa atau siswa dituntut untuk berpikir dan menggunakan strategi penyelidikan masalah yang meyakinkan baginya, dengan demikian pembelajaran pendekatan open-ended dapat membantu mahasiswa atau siswa mengembangkan kemampuan berpikir kreatif dan memberikan kebebasan yang terkendali, menciptakan kehangatan dalam pembelajaran dan memperhatikan motivasi belajar mahasiswa atau siswa dalam proses pembelajaran sehingga dapat memberikan kemampuan berpikir kreatif mahasiswa atau siswa yang lebih optimal.

2. Ketika menjaring data motivasi belajar mahasiswa dengan menggunakan tes motivasi belajar dengan 30 butir pernyataan dengan beberapa soal yang cukup panjang narasinya hendaknya diberikan waktu yang sesuai dan diperlukan dosen pendamping peneliti untuk melaksanakannya.

3. Dalam mengontrol kegiatan siswa satu persatu dalam proses pembelajaran dengan pendekatan open-ended diperlukan waktu yang sesuai sehubungan dengan ketercapaian tujuan peneltian.

4. Penelitian ini hendaknya dapat digabung dengan penelitian kualitatif sehingga proses belajar siswa dapat terekam dengan baik.
5. Penelitian ini masih perlu diuji lebih lanjut pada sampel yang lebih besar untuk mengurangi pengaruh statistik sampel yang terbatas.

\section{DAFTAR PUSTAKA}

Abdurrahman, M. 2003. Pendidikan Bagi Anak Berkesulitan Belajar. Jakarta: Rineka Cipta.

Ali, M. 2008. Terjemahan: Classroom Assessment, (Online), (http://alkhafy.blogspot.com, diakses 14 Desember 2008).

Anderson, dkk. 2001. A Taxonomy for Learning Teaching and Assessing: A Revition of Bloom's Taxonomy of Educational Objectives, New York: Longman.

Arikunto, S. 1999. Dasar-Dasar Evaluasi Pendidikan. Jakarta: Bumi Aksara.

Budiyono, 2009. Peningkatan Kualitas Pembelajaran Matematika Melalui Penilaian yang Efektif, (Online), (http://www.uns.ac.id, diaks13 Juli 2009).

Buzan, T. 2002. Sepuluh Cara Jadi Orang yang Jenius Kreatif. Jakarta: Gramedia.

Gagne and Briggs. 1997. The Conditioning of Learning. New York: Holt Rinchard and Winston.

Hancock, C.L. 1995. Enhancing Mathematics Learning With Open ended Question, Assesment Standard for School Mathematics. 86(9).

Hassoubah, I.Z. 2007. Kreatif dan Kritis. Bandung: Nuansa.

Karnasih, I. 1997. Prospek Pendidikan Matematika di Sumatera Utara. Disampaikan Pada Seminar Sehari 5 Nopember 2001.

Munandar, S.C.U. 1999. Kreativitas dan Keberbakakatan, Strategi MewujudkanKreatif \& Bakat. Jakarta: PT. Gramedia Pustaka Umum.

Nainggolan, P. 2009. Pengaruh Pendekatan Matematika Realistik dan Motivasi Belajar Siswa Terhadap Kemampuan Pemodelan Matematika Siswa SMP di Lubuk Pakam. Tesis tidak diterbitkan. Medan: Unimed.

Napitupulu, E. 2008. Pengaruh Model Pembelajaran Terhadap Hasil Belajar 
Matematika Siswa SMP Swasta PAB Helvetia Kota Medan. Unimed: Jurnal Pendidikan Matematika Vol.1 No.1 Edisi Juni 2008.

Pannen, P. 2004. Pembelajaran Kreatif Berbasis Seni Lokal. FKIP: Universitas Terbuka.

Pehkonen, E. 1997. The State of Art in Mathematical Creativity. (http://www.fizkarlsruhe.de//fiz/publicati ons/zdm) ZDM Volum 29 Juni 1997. Number 3. Electronic Edition ISSN 1615-679X.

Russeffendi, E.T. 1988. Pengantar Kepada Membantu Guru Mengembangkan. Bandung: Tarsito.
Semiawan, C. 2009. Kreativitas Keberbakatan. Jakarta: PT. Indeks.

Siswandi. 2009. Membangkitkan Kreativitas Sekolah,

(Online), (http://nazwadzulfa.wordpress.com, diakses 10 Oktober 2009).

Siswono. 2005. Pengembangan Tingkat Berpikir Kreatif Siswa dalam Matematika. Surabaya: Unesa.

Suherman, E. 1999. Strategi Belajar Mengajar Matematika. Universitas Terbuka: FKIP.

Sudjana. 2005. Metode Statistika. Bandung: Tarsito.

TIM MKPBM. 2001. Strategi Pembelajaran Matematika Kontemporer. Jurusan Pendidikan Matematika. Bandung: FMIPA UPI. 